\title{
ANALISIS PENGARUH PEMBERIAN MOTIVASI TERHADAP KINERJA KARYAWAN DI PT. BANK SYARIAH MANDIRI CABANG PANYABUNGAN
}

\author{
Ian Alfian ${ }^{1}$
}

\begin{abstract}
ABSTRAK
Penelitian yang dilakukan bertujuan untuk mengetahui pengaruh pemberian motivasi terhadap kinerja karyawan di PT Bank Syariah Mandiri Cabang Panyabungan. Metode yang digunakan dengan pendekatan kuantitatif. Hasil penelitian bahwa pemberian motivasi berpengaruh signifikan terhadap kinerja karyawan di PT Bank Syariah Mandiri Cabang Panyabungan. Hal tersebut dapat dilihat dari uji hipotesis dimana koefisien determinasi $\left(R^{2}\right)$ menunjukkan sebesar 0.714 atau $71.4 \%$, artinya bahwa variabel kinerja dapat diterangkan oleh variabel motivasi sebesar $71.4 \%$ sedangkan sisanya $28.6 \%$ diterangkan oleh variabel lain diluar penelitian. Pada uji $t$ diperoleh $t_{\text {hitung }}$ sebesar 5.469. artinya $t_{\text {hitung }}(5.469)>t_{\text {tabel }}(1.782)$ dan $P_{\text {value }}(0.00)<\alpha(0.05)$, artinya $H_{a}$ diterima dan $H_{0}$ ditolak. Sedangkan model regresi yang terbentuk menyatakan bahwa motivasi memberikan pengaruh yang signifikan terhadap kinerja dengan koefisien 1.004 yang berarti bahwa jika motivasi yang diberikan sebanyak 1 kali maka kinerja akan naik sebesar 1.004.
\end{abstract}

Kata Kunci: Motivasi, Kinerja, Karyawan

ABSTRACT

The research conducted aims to obtain information about support for employees at PT Bank Syariah Mandiri Panyabungan Branch. The method used is quantitative. The results of the study support significant motivation for the performance of employees at PT Bank Syariah Mandiri Panyabungan Branch. It can be seen from the hypothesis test where the coefficient of determination (R2) shows 0.714 or $71.4 \%$, which means that the performance variable can be explained by the motivation variable at $71.4 \%$ while accepted $28.6 \%$ is explained by other variables through research. In the test obtained tcount of 5.469. it means tcount $(5,469)>$ ttable $(1,782)$ and Pvalue $(0,00)<\alpha(0,05)$, meaning that $\mathrm{Ha}$ is accepted and $\mathrm{HO}$ is rejected. While the regression model that produces motivation gives a significant effect on the performance with a coefficient of 1.004, which means that motivation is given 1 time, the performance will increase by 1.004.

Keywords: Motivation, Performance, Employees

\footnotetext{
${ }^{1}$ Dosen STAIN Mandailing Nata/ Ianalfian@stain-madina.ac.id
} 


\section{PENDAHULUAN}

Perusahaan yang sukses ialah perusahaan yang menjaga asset nya dengan sangat baik. Salah satu asset perusahaan itu adalah karyawan. Karyawan yang diperlakukan dengan sangat baik akan memberikan kontribusi yang maksimal dan optimal bagi perkembangan perusahaannya. Ada tiga kelompok karyawan yaitu terbaik, rata-rata, dan rendah.

1 Karyawan terbaik mampu memberikan solusi pada perusahaan tanpa disuruh, karyawan rata-rata mampu bekerja rutin dengan baik, dan karyawan rendah adalah biang gosip dan menjelekkan perusahaan. ${ }^{2}$

Untuk mencapai jenjang karir dan kesuksesannya karyawan dituntut harus mampu mengembangkan dan mengoptimalkan segala kemampuan dan kehaliannya. Seorang karyawan harus mampu mengevaluasi pekerjaannya untuk menjadi lebih baik lagi. Sebagian karyawan merasa nyaman dengan pekerjaannya dan sebagian lagi merasa bosan dan jenuh atas pekerjaan yang selalu rutin setiap harinya. ${ }^{3}$ Rasa jenuh dan bosan memang tidak bisa dihilangkan begitu saja tetapi haruslah dikelola dengan baik bagi karyawan. Salah satunya karyawan membutuhkan motivasi dan pimpinan agar tetap menikmati pekerjaannya dan tetap menghasilkan kinerja yang baik.

Motivasi dan pimpinan yang diberikan perusahaan akan menambah gairah dan semangat dalam bekerja. Meskipun motivasi berkaitan dengan menginspirasi orang untuk bekerja, tetapi sebenarnya ada dua tipe motivasi, yaitu motivasi positif dan negatif. Motivasi positif yaitu motivasi yang diberikan kepada seseorang untuk hal hal yang baik serta untuk memperbaiki diri lebih baik lagi. Untuk itu, mereka disediakan sumber-sumber yang memadai dan mendapatkan penghargaan atas kinerja mereka. Motivasi positif berusaha memberikan iklim yang lebih cerah, bersemangat, dan optimis dalam organisasi. Sedangkan motivasi negatif yaitu adanya rasa takut bagi karyawan yang tidak melakukan pekerjaan dengan baik serta bertujuan mengendalikan upayaupaya negatif dalam lingkup pekerjaan. Motivasi negatif dapat berupa finansial, misalnya gaji dikurangi bila kinerjanya di bawah standar. Motivasi negatif nonfinansial, misalnya pemberian peringatan, pengurangan fasilitas, dan pengawasan yang lebih besar dalam pekerjaanya.

Secara umum manusia melakukan sesuatu merupakan atas kesadaran dirinya sendiri serta selalu didorong oleh keinginan untuk mencapai tujuan tertentu. Sehingga motivasi sangat diperlukan bagi seorang karyawan. Motivasi yaitu kemauan untuk berbuat sesuatu, sedangkan motif merupakan kebutuhan, keinginan, dorongan, atau implus. Motivasi sangat bergantung pada kekuatan motifnya. Motif yang memiliki kekuatan yang sangat besarlah yang akan menentukan prilaku seseorang. Biasanya ketika seseorang telah mencapai kepuasan atau menemui kegagalan, motif seseorang juga akan berkurang. ${ }^{4}$ Bernardine R. Wirjana menyatakan "Motivasi adalah salah satu faktor penting yang menentukan efesiensi organisasi". 5 Semua fasilitas organisasi akan terbuang sia-sia bila orang-orang tidak termotivasi untuk menggunakan fasilitas tersebut 
secara efektif. Tiap supervisor dalam organisasi harus memotivasi karyawan atau anggota untuk perilaku yang tepat. Pimpinan yang memiliki kemampuan dan dalam memberikan motivasi yang baik bagi karyawannya maka akan memiliki kemajuan perusahaan dan katyawan juga memiliki prestasi kerja. Sehingga motivasi kerja sangat berpengaruh positif dan signifikan terhadap kinerja karyawan.

Menurut Veinthal Rivai "kinerja adalah tolak ukur bagi seorang pimpinan untuk mengambil suatu keputusan penting misalnya promosi, transfer serta pemutusan hubungan kerja. ${ }^{6}$ Hasil kerja karyawan dapat dilihat dari penyelesaian masalah dan produktivitas mereka dalam bekerja. Dengan demikian evaluasi kinerja dapat memperbaiki atau meningkatkan prestasi. ${ }^{7}$

Penelitian yang dilakukan oleh Dien Mardiana Yulianti pada tahun 2015 dalam Jurnal Ilmiah Prodi Manajemen Universitas Pamulang Vol. 3, No.1, Oktober 2015 menyatakan bahwa motivasi kerja berpengaruh positif dan signifikan terhadap kinerja karyawan. Selain itu juga penelitian yang dilakukan oleh Yuni Afriani pada tahun 2017 dalam JOM FISIP Vol. 34 No. 1 - Februari 2017 mendukung penelitian sebelumnya yang menyatakan bahwa motivasi berpengaruh positif dan signifikan terhadap kinerja karyawan. Dari penelitian terdahulu, hubungan antara motivasi dan kinerja berbanding lurus, artinya bahwa semakin tinggi motivasi karyawan yang diberikan maka kinerja yang dihasilkan juga tinggi.

\section{Tinjauan Pustaka}

\section{a. Pengertian Kinerja}

Kinerja karyawan dalam sebuah perusahaan mempunyai tingkat kemampuan yang berbeda-beda tergantung dari individual seseorang. Kinerja seseorang tersebut tergantung pada kombinasi dari kemampuan, usaha, dan kesempatan yang diperoleh.

Gomez-Mejia Al menyatakan bahwa "kinerja adalah gabungan antara keberhasilan keuangan (perusahaan) dan sejauh mana perusahaaan itu bisa menyejahterakan keberhasilan keuangan". 8 Pakar lain tidak sependapat bila kinerja hanya dikaitkan dengan keberhasilan keuangan. Diantara mereka, Mayer dan Zucker menyatakan bahwa "kinerja perusahaan adalah sebuah fungsi pencapaian tujuan atau sasaran". 9

Kemudian konsep kinerja menurut Rummler dan Brache mengemukakan ada tiga level kinerja, yaitu:

1) Kinerja organisasi, yaitu hasil outcome unit analisis organisasi mulai dari tujuan organisasi, rancangan organisasi serta manajemen organisasi.

2) Kinerja proses, yaitu kinerja pada tahapan dalam menghasilkan produk atau pelayanan. Kinerja proses ini dipengaruhi oleh tujuan proses, rancangan proses, dan manajemen proses. 
3) Kinerja individu/pekerjaan, yaitu pencapaian atau efektivitas pada tingkat pegawai atau pekerjaan. Kinerja pekerjaan ini dipengaruhi oleh tujuan pekerjaan, rancangan pekerjaan, dan manajemen pekerjaan serta karakteristik individu. ${ }^{10}$

\section{b. Dimensi Kinerja}

Indikator kinerja merupakan aspek yang menjadi tolak ukur dalam menilai kinerja. Menurut John Miner ada 4 dimensi yang dapat dijadikan sebagai tolak ukur dalam menilai kinerja, yaitu:

1) Kualitas hasil merupakan tingkat kesalahan, kerusakan, dan kecermatan.

2) Kuantitas, merupakan jumlah pekerjaan yang dihasilkan.

3) Penggunaan waktu dalam kerja, merupakan tingkat ketidakhadiran, keterlambatan, waktu kerja efektif/ jam kerja hilang.

4) Kerja sama dengan pihak lain dalam bekerja. ${ }^{11}$

Dari beberapa dimensi kinerja di atas, kualitas hasil dan kuantitas keluaran masuk kedalam aspek keluaran atau aspek hasil pekerjaan. Sedangkan penggunaan waktu dalam bekerja dan kerjasama masuk dalam aspek perilaku individu. Dari empat dimensi kinerja tersebut cenderung mengukur kinerja pada level individu.

Tujuan ukuran kinerja adalah untuk mengukur apakah pekerjaan kita telah memberikan hasil yang diinginkan sudah tercapai atau belum serta kuantitas output yang diproduksi dalam bekerja. $^{12}$

\section{c. Pengertian Motivasi}

Motivasi berasal dari bahasa latin yaitu Mavare yang berarti dorongan atau daya penggerak. ${ }^{13}$ Motivasi dibutuhkan karena dapat memberikan kemampuan dan keterampilan dalam mewujudkan tujuan perusahaan. Motivasi mempersoalkan bagaimana caranya mendorong gairah kerja bawahan agar mereka mau bekerja keras dengan memberikan semua kemampuan dan keterampilannya untuk mewujudkan tujuan perusahaan. Untuk mencapai produktivitas kerja yang tinggi maka motivasi seorang pimpinan sangat dibutuhkan agar karyawan mau bekerja keras dan antusiasme karyawan terhadap sesuatu pekerjaan lebih lagi. Adapun alas an mengapa pemimpin harus melakukan motivasi terhadap karyawan yaitu :

1) Pimpinan harus menyelesaikan pekerjaan untuk mencapai tujuan dengan membagibagikan pekerjaan terhadap karyawan

2) Tidak semua pemimpin mampu mengerjakan suatu pekerjaan sehingga dibutuhkan bawahan yang mampu mengerjakan pekerjaan tersebut.

3) Agar terpeliharanya serta untuk peningkatan gairah kerja bawahan dalam menyelsaikan tugas-tugasnya

4) Sebagai pemberian reward (penghargaan) bagi karywan yang berprestasi. ${ }^{14}$ 


\section{d. Faktor-faktor Yang Mempengaruhi Motivasi}

Untuk meningkatkan motivasi banyak faktor yang mempengaruhinya yaitu faktor intrinstik dan faktor ekstrinsik. Adapun faktor intrinstik yaitu dorongan yang timbul dari dalam diri seseorang itu sendiri untuk bekerja guna mencapai suatu manfaat yang diinginkan diri sendiri maupun orang lain. Menurut Amini "motivasi intrinstik adalah dorongan yang merupakan keinginan murni dari individu untuk melakukan sesuatu". ${ }^{15}$

Sementara motivasi ekstrinsik yaitu dorongan yang datang dari luar dirinya berbentuk sesuatu yang mengharuskan seseorang bekerja agar kebutuhan dapat dipenuhi. Sesuatu yang dapat mendorong itu biasanya berbentuk material (Hadiah).

\section{e. Cara Pemberian Motivasi Oleh Pimpinan}

Pimpinan yang baik adalah pimpinan yang mampu memotivasi karyawannya dengan baik pula yang mampu mengubah dan memberikan efek positip bagi karyawan demi kemajuan perusahaan. Memotivasi bukan sekedar memberikan pengarahan namun harus dapat memastikan bahwa lingkungan dimana mereka bekerja memenuhi sejumlah kebutuhan manusia yang penting. Adapun beberapa cara perlu dilakukan seorang pemimpin dalam memberikan motivasi kepada karyawan yaitu:

1) Menilai Sikap

2) Menjadi Pimpinan yang baik

3) Komunikasi yang baik

4) Membiasakan diri untuk bertanggung jawab

5) Kerjasama

6) Inisiatif

\section{f. Tujuan Pemberian Motivasi}

Menurut Melayu S.P tujuan pemberian motivasi yang diberikan kepada karyawan adalah sebagai berikut:

1) Meningkatkan semangat kerja dan gairah karyawan.

2) Memberikan peningkatan moral dan kepuasan kerja karyawan.

3) Meningkatkan produktivitas kerja karyawan.

4) Mempertahankan loyalitas dan kestabilan karyawan perusahaan.

5) Meningkatkan kedisiplinan dan menurunkan tingkat absensi karyawan.

6) Mengefektifkan pengadaan karyawan.

7) Menciptakan suasana dan hubungan kerja yang baik.meningkatkan kreativitas dan partisipasi karyawan.

8) Meningkatkan tingkat kesejahteraan karyawan. 
9) Mempertinggi rasa tanggung jawab karyawan terhadap tugas-tugasnya.

10) Meningkatkan efesiensi penggunaan alat-alat dan bahan baku. ${ }^{16}$

\section{Penelitian Terdahulu}

Penelitian terdahulu digunakan sebagai pendukung dalam penelitian yang akan dilakukan. Adapun penelitian terdahulu yang digunakan yaitu:

1. Penelitian dengan judul "Pengaruh Pemberian Motivasi Terhadap Kinerja Karyawan Pada Koperasi Rajawali Telkom Jakarta Selatan" Oleh Dien Mardiana Yulianti dalam Jurnal Ilmiah Prodi Manajemen Universitas Pamulang Vol. 3, No.1, Oktober 2015. Penelitian ini menggunakan metode analisis regresi sederhana. Hasil dalam penelitian ini yaitu "motivasi berpengaruh signifikan pada kepuasaan kerja, motivasi tidak berpengaruh signifikan terhadap kinerja pegawai dan kepuasaan kerja berpengaruh signifikan terhadap kinerja pegawai". ${ }^{17}$

2. Penelitian dengan judul "Pengaruh Pemberian Motivasi Terhadap Kinerja Karyawan (Studi Kasus PT.Samudranesia Tour And Travel Pekanbaru)" Oleh Yuni Afriani dalam Jurnal JOM FISIP vol. 34 No. 1 - Februari 2017. Penelitian ini menggunakan metode kuantitatif dengan menyebar angket. Hasil dari penelitian ini yaitu variabel motivasi berpengaruh signifikan terhadap kinerja. ${ }^{18}$

Dari beberapa penelitian terdahulu diatas, yang membedakan dengan penelitian ini yaitu peneliti melakukan pada tahun 2019 dan berada ditempat yang berbeda yaitu di PT. Bank Syariah Mandiri Cabang Panyabungan, sedangkan persamaan nya yaitu dengan menggunakan variabel yang sama.

\section{Kerangka Teoritis}

Bekerja pada suatu lembaga bank merupakan pekerjaan yang diidamkan sebagaian besar orang. Namun bekerja di bank di lepas yang dinamakan bosan dan jenuh akibat Pekerjaan yang dilakukan merupakan salah satu pekerjaan atau aktivitas yang selalu dilakukan secara berulang. Rutinitas pekerjaan yang sama setiap hari itulah yang dilakukan karyawan. Pada saat kondisi pekerjaan seperti ini karyawan sangat rentan terhadap kejenuhan yang mempengaruhi kinerja karyawan. Sehingga membutuhkan motivasi dari sebuah pemimpin perusahaan yang bisa membuat karyawan termotivasi dalam bekerja dan kinerja perusahaan meningkat seiring meningkatnya kinerja karyawan. Oleh sebab itu perlu dikaji dan diteliti apakah motivasi berpengaruh dan bagaimana pengaruh motivasi tersebut terhadap kinerja karyawan.

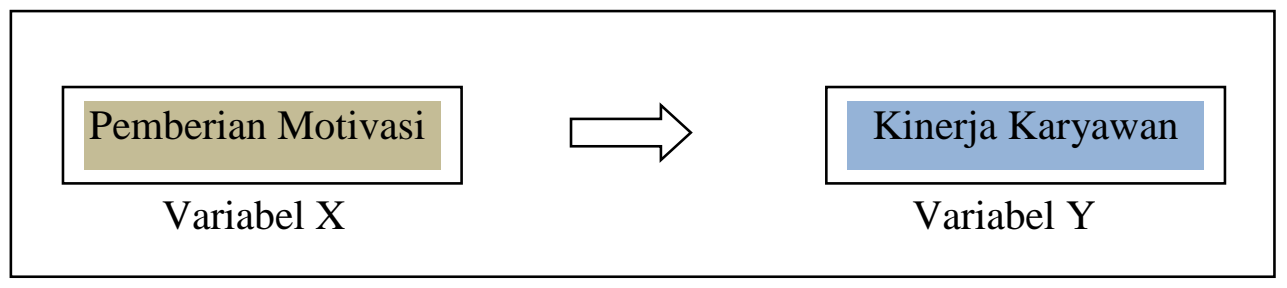

Gambar. 1 Kerangka Berfikir 


\section{METODE PENELITIAN}

Metode yang digunakan dalam penelitian ini yaitu menggunakan metode penelitian kuantitatif. Penelitian ini merupakan penelitian kausal dengan bertujuan mengetahui hubungan sebab akibat antara variabel pemberian motivasi terhadap Kinerja Karyawan Pada PT. Bank Syariah Mandiri Cabang Panyabungan.

Untuk menjawab permsalahan yang sudah dirumuskan, tujuan penelitian serta dalam melalukan pengujian hipotesis maka penelitian ini bersifat eksplanasi (explanatory research). Penelitian yang bersifat eksplanasi bermaksud menjelaskan kedudukan variabel-variabel yang diteliti serta hubungan dan pengaruh antar variabel yang yang lain.

Berdasarkan hubungan antar variabel, variabel laten eksogen merupakan variabel independen (bebas) yang mempengaruhi variabel dependen (terikat). Dalam penelitian ini yang menjadi variabel laten eksogen adalah pemberian motivasi (X). Sedangkan Variabel laten endogen, merupakan variabel dependen yang dipengaruhi oleh variabel independen. Dalam penelitian ini yang menjadi variabel laten endogen adalah kinerja karyawan (Y).

\section{HASIL DAN PEMBAHASAN}

\section{Analisis Korelasi}

Analisis korelasi merupakan analisis untuk mengukur kekuatan hubungan dua variabel yang mempunyai dua distribusi data normal. Dalam penelitian ini, analisis korelasi dilakukan untuk mengetahui sejauh mana korelasi atau derajat antara pemberian motivasi terhadap kinerja karyawan.

\section{Tabel 2. Hasil Analisis Korelasi}

Model Summary

\begin{tabular}{|l|l|l|l|l|}
\hline Model & $\mathrm{R}$ & R Square & $\begin{array}{l}\text { Adjusted R } \\
\text { Square }\end{array}$ & $\begin{array}{l}\text { Std. Error of the } \\
\text { Estimate }\end{array}$ \\
\hline 1 &, $845^{\mathrm{a}}$ &, 714 &, 690 & 4,890 \\
\hline
\end{tabular}

a. Predictors: (Constant), Pemberian_Motivasi

b. Dependent Variable: Kinerja_Karyawan

Sumber: Hasil Output Spss versi 17.0 
Tabel 3. Interpretasi nilai $\mathbf{r}$

\begin{tabular}{|l|l|}
\hline Interval Koefisien & Tingkat Hubunngan \\
\hline $0,00-0,199$ & Sangat Rendah \\
\hline $0,20-0,399$ & Rendah \\
\hline $0,40-0,599$ & Sedang \\
\hline $0,60-0,799$ & Kuat \\
\hline $0,80-1,000$ & Sangat Kuat \\
\hline
\end{tabular}

Sumber: Sugiono (2008: 148)

Dari hasil analisis korelasi sederhana (r) didapat korelasi antara pemberian motivasi terhadap kinerja karyawan (r) adalah 0,845. Hal ini menunjukkan bahwa terjadi hubungan yang sangat kuat antara kualitas pemberian motivasi terhadap kinerja karyawan. Sedangkan arah hubungan adalah positif karena nilai $r$ positif, berarti semakin besar pemberian motivasi yang diberikan maka semakin besar kinerja karyawan. Nilai 0,845 (berada di antara 0,80-1,000) menunjukkan adanya hubungan antara variabel $\mathrm{X}$ dan variabel $\mathrm{Y}$ kuat, hal ini sesuai dengan nilai interpretasi korelasi.

\section{Analisis Regresi Linier Sederhana}

Tabel 4. Model Summary

\begin{tabular}{|c|c|c|c|c|c|}
\hline \multirow[b]{2}{*}{ Model } & \multirow[b]{2}{*}{$\mathrm{R}$} & \multirow[b]{2}{*}{ R Square } & \multirow{2}{*}{$\begin{array}{l}\text { Adjusted R } \\
\text { Square }\end{array}$} & \multirow{2}{*}{$\begin{array}{l}\text { Std. Error of the } \\
\text { Estimate }\end{array}$} & Durbin-Watson \\
\hline & & & & & \\
\hline 1 & $845^{\mathrm{a}}$ &, 714 &, 690 & 4,890 & 2,168 \\
\hline
\end{tabular}

a. Predictors: (Constant), Pemberian_Motivasi

b. Dependent Variable: Kinerja_Karyawan

r dalam analisis regresi sederhana menunjukkan korelasi sederhana yaitu korelasi antara satu variabel independen terhadap satu variabel devenden. Angka r didapat 0,845 artinya korelasi antara variabel pemberian motivasi dan variabel kinerja karyawan adalah kuat. Hal ini berarti terjadi hubungan yang erat karena nilai mendekati 1 .

R Square (r2) yaitu menunjukkan nilai koefisien determinasi. Angka ini akan di ubah ke bentuk persen, yang artinya presentase sumbangan pengaruh variabel 
independen terhadap variabel dependen. Nilai $\mathrm{r} 2$ sebesar 0,714 atau $71,4 \%$ artinya kinerja karyawan dipengaruhi oleh variabel pemberian motivasi dengan kontribusi sebesar $71,4 \%$, sedangkan $28,6 \%$ sisanya dipengaruhi oleh variabel lain yang tidak diteliti dalam penelitian ini.

\section{Uji Hipotesis (Uji t)}

Uji t bertujuan untuk mengetahui besarnya pengaruh variabel independen terhadap variabel dependen. Kesimpulan atas penerimaan hipotesis berdasarkan nilai t hitung adalah sebagai berikut:

\section{Tabel 5. Hasil Analisis Regresi Linier Sederhana}

\section{Coefficients $^{\mathrm{a}}$}

\begin{tabular}{|c|c|c|c|c|c|}
\hline \multirow[b]{2}{*}{ Model } & \multicolumn{2}{|c|}{$\begin{array}{l}\text { Unstandardized } \\
\text { Coefficients }\end{array}$} & \multirow{2}{*}{\begin{tabular}{|l}
$\begin{array}{l}\text { Standardized } \\
\text { Coefficients }\end{array}$ \\
Beta
\end{tabular}} & \multirow[b]{2}{*}{$t$} & \multirow[b]{2}{*}{ Sig. } \\
\hline & B & Std. Error & & & \\
\hline $1 \quad$ (Constant) & 3,733 & 8,380 & &, 446 &, 664 \\
\hline $\begin{array}{l}\text { Pemberian } \\
\text { Motivasi }\end{array}$ & 1,004 &, 184 &, 845 & 5,469 &, 000 \\
\hline
\end{tabular}

a. Dependent Variable: Kinerja_Karyawan

Berdasarkan tabel di atas maka, disimpulkan:

a. Dari kolom $t, t$ hitung sebesar 5,469 dengan $t$ tabel sebesar 1,782. Artinya bahwa t hitung > t tabel yaitu 5,469 > 1,782. Maka Ha diterima dan H0 ditolak. Artinya bahwa pemberian motivasi berpengaruh terhadap kinerja karyawan.

b. Pada kolom Sig., Pvalue sebesar 0,00 dengan taraf signifikan $(\alpha)$ sebesar 0,05. Artinya bahwa Pvalue $<\alpha$ yaitu $0,00<0,05$. Maka diperoleh bahwa Ha diterima H0 ditolak. Artinya pemberian motivasi berpengaruh signifikan terhadap kinerja karyawan.

Jadi berdasarkan kedua kesimpulan di atas maka, Ha diterima dan H0 ditolak. Artinya pemberian motivasi memiliki pengaruh yang signifikan terhadap kinerja karyawan.

Pada kolom Understandardized Coeficient bagian standar error variabel diperoleh sebesar 0,184. Dan dari tabel tersebut pada kolom yang sama bagian B dapat dibuat persamaan regresi penelitian ini sebagai berikut: $\hat{\mathbf{y}}=\mathbf{a}+\mathbf{b x}$. 
Maka hasil model regresi yang terbentuk adalah $\hat{\mathbf{y}}=\mathbf{3 , 7 3 3}+\mathbf{1 , 0 0 4 x}$. Arti dari model yang diperoleh adalah:

a. Nilai konstanta (a) sebesar 3,733, artinya bahwa jika pemberian motivasi diabaikan, maka kinerja karyawan sebesar 3,733 kali.

b. Nilai koefisien regresi variabel pemberian motivasi (b) adalah 1,004, maka ini dapat diartikan bahwa setiap pemberian pemberian motivasi sebesar 1 kali, maka kinerja karyawan juga akan meningkat 1,004 kali.

Jadi berdasarkan hasil pengolahan data dapat dirumuskan bahwa pemberian motivasi mempunyai pengaruh yang signifikan terhadap kinerja karyawan, dimana apabila pemberian motivasi naik sebesar 1 kali maka kinerja karyawan akan naik 1,004 kali.

\section{Pembahasan Hasil Penelitian}

Motivasi adalah segala sesuatu yang menjadi pendorong bagi setiap individu untuk melakukan pekerjaannya dengan tujuan untuk memenuhi kebutuhan dan meningkatkan aktivitas kerja, sehingga dapat memperoleh tujuan dan hasil yang maksimal. Bagi seorang karyawan motivasi bertujuan untuk meningkatkan kinerja karyawan sehingga mencapai tujuan perusahaan sesuai yang diharapkan.

Adapun kinerja adalah gabungan antara keberhasilan keuangan (perusahaan) dan sejauh mana perusahaaan itu bisa menyejahterakan keberhasilan keuangan. Akan tetapi kinerja tidak hanya dikaitkan dengan keberhasilan keuangan saja, melainkan kinerja juga dapat didefenisikan sebagai sebuah fungsi pencapaian tujuan atau sasaran.

Motivasi berpengaruh terhadap kinerja karyawan, dari hasil analisis dan pengujian hipotesis yang telah dilakukan, maka diperoleh hasil yang menunjukkan bahwa hipotesis alternatif yang menyatakan ada pengaruh diantara kedua variabel dapat diterima. Hal ini dibuktikan berdasarkan perhitungan hasil uji t yang diperoleh sebesar $\mathrm{t}$ = 5.469. Hasil analisis data menunjukkan bahwa t hitung $>\mathrm{t}$ tabel atau $5.469>1.782$.

Berdasarkan perolehan skor tersebut, maka diketahui R2 sebesar 0.714 atau $71.4 \%$, yang berarti variabel motivasi mampu menerangkan variabel kinerja sebesar $71.4 \%$ sedangkan $28.6 \%$ lagi dipengaruhi oleh variabel lain di luar penelitian.

Pada tabel coefficient kolom Sig variabel motivasi sebesar 0.00 dengan taraf signifikan $(\alpha)$ sebesar 0,05 . Artinya bahwa nilai sig $<$ dari taraf signifikan yaitu $0.00<$ 0.05. Maka diperoleh bahwa Ha diterima H0 ditolak. Artinya motivasi memiliki pengaruh yang signifikan terhadap kinerja karyawan.

\section{KESIMPULAN}

Terdapat pengaruh pemberian motivasi terhadap kinerja di PT. Bank Syariah Mandiri Cabang Panyabungan. Hal ini ditunjukkan analisis korelasi $r=0,845$ yang 
berarti ada hubungan yang sangat kuat antara pemberian motivasi terhadap kinerja karyawan di PT. Bank Syariah Mandiri Cabang Panyabungan. Berdasarkan perhitungan koefisien determinasi, maka diketahui $\mathrm{r} 2$ sebesar 0,714 atau $71.4 \%$, yang berarti variabel pemberian motivasi mampu menerangkan variabel kinerja karyawan sebesar 71.4\% sedangkan $28.6 \%$ lagi dipengaruhi oleh variabel lain yang tidak diteliti dalam penelitian ini. Dari analisis regresi diperoleh persamaan regresi berikut: $\hat{y}=3,733+$ $1,004 x$. Artinya setiap pemberian motivasi sebesar 1 kali akan meningkatkan kinerja karyawan sebesar 1,004 kali.

\section{Catatan Kaki}

${ }^{1}$ Yusuf Suhardi, Kewirausahaan (Jakarta: Ghalia Indonesia, 2011), hlm. 121.

${ }^{2}$ Ibid.

${ }^{3}$ Gary Dessler, Manajemen Sumber Daya Insani (Jakarta: PT Indeks, 2009), hlm. 8.

${ }_{5}^{4}$ Bukhari Alma, Kewirausahaan, (Bandung: Alfabeta, 2009), hlm. 89.

${ }^{5}$ Bernardine R. Wirjana, MSW, Mencapai Manajemen Berkualitas(Yogyakarta: Andi, 2007), hlm. 85.

${ }^{6}$ Veinthal Rivai M.B.A, Kepeminpimpinan dan Perilaku Organisasi(Jakarta: PT Raja Grafindo Persada, 2008), hlm. 426.

${ }^{7}$ Ike Kusdyah Rachmawati, Manajemen Sumber Daya Manusia, (Yogyakarta: Andi, 2008), hlm. 124.

${ }^{8}$ David Rees \& Richard McBain, People Management Teori\& Strategi: Tantangan \& Peluang (Jakarta: Kencana, 2007), hlm. 74.

${ }^{9}$ Ibid.

${ }^{10}$ Ibid.

${ }^{11}$ Ibid.

${ }^{12}$ Wibowo, Manajemen Kinerja (Jakarta: PT. Raja Grafindo Persada, 2012), hlm. 232.

${ }^{13}$ Malayu S.P, Manajemen: Dasar, Pengertian, Dan Masalah (Jakarta: Bumi Aksara, 2006), hlm.216.

${ }^{14}$ Ibid,. hlm.216.

${ }^{15}$ Amini, Perilaku Organisasi (Bandung : Cipta Pustaka Media, 2004), hlm. 63.

${ }_{17}^{16}$ MalayuS.P, Manajemen: Dasar, Pengertian, Dan Masalah,... hlm. 221.

17 Dien Mardiana Yulianti. Pengaruh Pemberian Motivasi Terhadap Kinerja Karyawan Pada Koperasi Rajawali Telkom Jakarta Selatan. Jurnal Ilmiah Prodi Manajemen Universitas Pamulang Vol. 3, No.1, Oktober 2015

${ }_{18}$ Yuni Afriani. Pengaruh Pemberian Motivasi Terhadap Kinerja Karyawan (Studi Kasus Pt.Samudranesia Tour And Travel Pekanbaru. Jurnal JOM FISIP vol. 34 No. 1 - Februari 2017

\section{DAFTAR PUSTAKA}

Amini. 2004. Perilaku Organisasi. Bandung : Cipta Pustaka Media.

Bukhari Alma. 2009. Kewirausahaan. Bandung: Alfabeta.

Bernardine R. Wirjana, MSW. 2007. Mencapai Manajemen Berkualitas. Yogyakarta: Andi

David Rees \& Richard McBain. 2007. People Management Teori\& Strategi: Tantangan \& Peluang. Jakarta: Kencana.

Ike Kusdyah Rachmawati. 2008. Manajemen Sumber Daya Manusia. Yogyakarta: Andi. Gary Dessler. 2009. Manajemen Sumber Daya Insani. Jakarta: PT Indeks.

Malayu S.P. 2006. Manajemen: Dasar, Pengertian, Dan Masalah. Jakarta: Bumi Aksara. Muchdarsyah Sinungan. 2008. Produktivitas Apa Dan Bagaimana. Jakarta: PT. Bumi Aksara. 
Veinthal Rivai M.B.A. 2008. Kepeminpimpinan dan Perilaku Organisas. Jakarta: PT Raja Grafindo Persada.

Wibowo. 2012. Manajemen Kinerja. Jakarta: PT. Raja Grafindo Persada.

Yusuf Suhardi. 2011. Kewirausahaan. Jakarta: Ghalia Indonesia.

http://www.banksumut.com/statis-34-profil.html

Dien Mardiana Yulianti. Pengaruh Pemberian Motivasi Terhadap Kinerja Karyawan Pada Koperasi Rajawali Telkom Jakarta Selatan. Jurnal Ilmiah Prodi Manajemen Universitas Pamulang Vol. 3, No.1, Oktober 2015.

Yuni Afriani. Pengaruh Pemberian Motivasi Terhadap Kinerja Karyawan (Studi Kasus Pt.Samudranesia Tour And Travel Pekanbaru. Jurnal JOM FISIP vol. 34 No. 1 - Februari 2017. 